\title{
Coronary endarterectomy: an old tool for patients currently operated on with coronary artery bypass grafting. Long-term results, risk factor analysis
}

\author{
Paolo Nardi, Marco Russo, Guglielmo Saitto, Emanuele Bovio, Sara Rita Vacirca, Carlo Bassano, \\ Antonio Scafuri, Antonio Pellegrino, Giovanni Ruvolo
}

Department of Cardiac Surgery, Tor Vergata University Policlinic, Rome, Italy

Kardiochirurgia i Torakochirurgia Polska 2018; 15 (4): 219-226

\begin{abstract}
Aim: Coronary endarterectomy (CE) may provide a useful adjunctive technique to coronary artery bypass grafting (CABG) in patients with diffuse coronary artery disease. Nevertheless, the incidence of complications still remains high, long-term results remain unclear, and no risk factors for late mortality have been completely described yet.

Material and methods: We retrospectively reviewed 90 consecutive patients ( $67 \pm 8.2$ years) undergoing isolated CABG in association with CE between 2006 and 2013. Mean follow-up was $75.1 \pm 36.2$ months (median: 84 months) and it was 100\% complete (6755/6755 patient-months).

Results: Operative mortality was $4.4 \%$, the incidence of perioperative myocardial infarction was $11 \%$. Ten-year survival was $83.3 \pm 4.1 \%$, freedom from cardiac death $92.7 \pm 2.9 \%$, and freedom from major adverse cardiac and cerebrovascular events $58.2 \pm 10.2 \%$. Independent predictors of late mortality were age older than 70 years at time of the surgery $(p=0.018)$ and chronic obstructive pulmonary disease $(p=0.036)$. Ten-year freedom from cardiac death was better after CE on the left descending coronary artery (LAD) $(93.2 \pm 3.3 \%)$ in comparison to CE not on the LAD (74.6 $\pm 10.2 \%)$, although this difference did not reach statistical significance $(p=0.102)$.

Conclusions: Although the incidence of perioperative myocardial infarction continues to be not negligible, in the presence of diffusely diseased coronary artery vessels CE associated with CABG appears to be a feasible adjunctive surgical tool, conferring satisfactory early and long-term outcomes. Coronary endarterectomy on the LAD confers a high probability of freedom from late cardiac death. Patients older than 70 years and those affected by a primary respiratory disease represent a new challenge on which to focus attention due to the increased risk of late death.
\end{abstract}

Key words: coronary endarterectomy, coronary artery bypass grafting.

\section{Streszczenie}

Cel: Endarterektomia wieńcowa (CE) jest przydatną techniką uzupełniającą pomostowanie aortalno-wieńcowe (CABG) u pacjentów z chorobą wieńcową. Wskaźnik występowania powikłań nadal jest jednak wysoki, wyniki długoterminowe są niejednoznaczne i nie określono w pełni czynników ryzyka śmiertelności późnej.

Materiał i metody: Badaniem retrospektywnym objęto 90 pacjentów (67 $\pm 8,2$ roku) poddanych izolowanej operacji CABG połączonej z CE w latach 2006-2013. Czas obserwacji wynosił średnio 75,1 $\pm 36,2$ miesiąca (mediana: 84 miesiące) i był w $100 \%$ pełny (6755/6755 osobomiesięcy).

Wyniki: Śmiertelność pooperacyjna wynosiła 4,4\%, a wskaźnik występowania okołooperacyjnego zawału - 11\%. Przeżycie dziesięcioletnie wynosiło $83,3 \pm 4,1 \%$, okres bez nagłej śmierci sercowej - 92,7 $\pm 2,9 \%$, a okres wolny od poważnych zdarzeń niepożądanych związanych z sercem i naczyniami mózgu $58,2 \pm 10,2 \%$. Niezależne czynniki prognostyczne dla śmiertelności późnej to wiek ponad 70 lat w czasie operacji $(p=0,018)$ oraz przewlekła obturacyjna choroba płuc (POChP) $(p=0,036)$. Wskaźniki czasu bez śmierci sercowej były lepsze po CE lewej gałęzi międzykomorowej (LAD) $(93,2 \pm 3,3 \%)$ w porównaniu z CE innego naczynia niż LAD (74,6 $\pm 10,2 \%)$, chociaż różnica ta nie była statystycznie istotna $(p=0,102)$.

Wnioski: Mimo że wskaźnik występowania zawału w okresie okołooperacyjnym jest nieistotny, w przypadku rozproszonych zmian w naczyniach wieńcowych zabieg CE połączony z CABG wydaje się przydatną metodą przynoszącą zadowalające wyniki w krótkiej i długiej perspektywie czasowej. Endarterektomia wieńcowa LAD zwiększa prawdopodobieństwo uniknięcia późnej śmierci sercowej. Chorzy w wieku ponad 70 lat oraz pacjenci z pierwotną chorobą układu oddechowego stanowią wyzwanie ze względu na podwyższone ryzyko późnego zgonu.

Słowa kluczowe: endarterektomia wieńcowa, pomostowanie aortalno-wieńcowe.

Address for correspondence: Marco Russo MD, Cardiac Surgery Division, Tor Vergata University Policlinic, Viale Oxford 81, 00133 Rome, Italy, phone: +39 0620903536, fax: +39 0620903538, e-mail: mar.russo1987@gmail.com

Received: 13.06 .2018 , accepted: 29.09.2018. 


\section{Introduction}

Coronary endarterectomy (CE) was introduced in the 1950 s as an operative technique with the aim to decrease angina in patients affected by coronary artery disease, and subsequently proposed in addition with coronary artery bypass grafting (CABG). However, long-term results remain unclear and many surgeons still have doubts regarding the real usefulness of this procedure [1, 2]. Moreover, in a recently published meta-analysis it was reported that, as compared with CABG alone, CE in addition to CABG increases not only operative mortality, but also the incidence of perioperative myocardial infarction, low-output cardiac syndrome and post-operative morbidity [3].

The typical profile of a patient candidate for surgical myocardial revascularization has drastically changed in the last two decades. Percutaneous coronary intervention $(\mathrm{PCI})$ has shown good results, and the current international guidelines encourage this approach even in patients affected by multivessel coronary artery disease [4]. Consequently, surgical patients are more complex, usually presenting a diffusive coronary artery disease. In particular, in the left anterior descending artery, a simple distal anastomosis could not achieve complete revascularization of the myocardium supplied by the side branches, i.e. diagonal or septal perforators affected by a diffuse atheromatous pathology. Furthermore, patients referred for coronary surgery are older, more frequently diabetic and affected by extra-cardiac co-morbidity, i.e. chronic obstructive pulmonary or kidney disease. These changes in surgical scenario led

Table I. Preoperative patients' characteristics

\begin{tabular}{|c|c|}
\hline Characteristic & $\begin{array}{l}\text { Overall } \\
(n=90)\end{array}$ \\
\hline Age, mean \pm SD [years] & $67.0 \pm 8.2$ \\
\hline Male gender, $n(\%)$ & $66(73.3)$ \\
\hline EuroSCORE II, mean \pm SD & $3.4 \pm 1.8$ \\
\hline CCS class $\geq 3, n(\%)$ & $47(52.2)$ \\
\hline BMI, mean $\pm \mathrm{SD}\left[\mathrm{kg} / \mathrm{m}^{2}\right]$ & $27.2 \pm 4.0$ \\
\hline Obesity, $n(\%)$ & $20(22.2)$ \\
\hline Hypertension, $n$ (\%) & $82(91.1)$ \\
\hline Dyslipidemia, $n(\%)$ & $39(43.3)$ \\
\hline Diabetes on insulin, $n(\%)$ & $18(20.0)$ \\
\hline Active smoker, $n(\%)$ & $23(25.5)$ \\
\hline Chronic renal dysfunction, $n(\%)$ & $7(7.8)$ \\
\hline Chronic obstructive pulmonary disease, $n(\%)$ & $9(10.0)$ \\
\hline Peripheral vascular disease, $n(\%)$ & $20(22.2)$ \\
\hline Recent MI, < 60 days, $n(\%)$ & $25(27.8)$ \\
\hline $\operatorname{LVEF}(\%)$, mean \pm SD & $49.6 \pm 9.9$ \\
\hline Left main stenosis > 50\%, $n(\%)$ & $23(25.5)$ \\
\hline Number of diseased vessels, mean \pm SD & $2.8 \pm 0.4$ \\
\hline Urgency, $n(\%)$ & $18(20.0)$ \\
\hline
\end{tabular}

BMI - body mass index, CCS - Canadian Cardiovascular Society class, LVEF - left ventricular ejection fraction, MI - myocardial infarction, SD - standard deviation. to CE being reconsidered as an adjunctive tool in selected patients undergoing $C A B G$, and the reassessment of the technique, its indications and evaluation of its outcomes are now mandatory.

\section{Aim}

The aim of the present study is to report our clinical experience of patients affected by diffusely diseased coronary artery vessels treated by means of CE in association with CABG during an 8-year surgical activity period, and to analyze independent predictors for late mortality that could better define the actual role of CE.

\section{Material and methods}

From January 2006 to December 2013, at the Cardiac Surgery Unit of the Tor Vergata University Policlinic of Rome, 90 consecutives patients ( $67.0 \pm 8.2$ years, 66 males) underwent CE plus CABG. Table I presents the main preoperative patients' characteristics.

Preoperatively, in the first period of the experience performing CE, we discontinued anti-platelet therapy in all patients affected by a stable coronary disease and switched to twice daily subcutaneous administration of heparin $100 \mathrm{IU} / \mathrm{kg}$; in contrast, in patients affected by acute coronary syndromes, i.e. unstable angina and non-ST elevation myocardial infarction, or submitted to a recent coronary stenting procedure, a single anti-platelet therapy was maintained until the day of surgery. In the last 3 years, as also subsequently recommended by the Eurolntervention Consensus of Physicians written in 2014 [5], single or, if required, dual anti-platelet aggregation therapy was maintained in all patients submitted to previous coronary stenting or in the setting of acute coronary syndromes, with or without the subcutaneous administration of heparin.

Different postoperative anti-platelet aggregation protocols were used according to patients' characteristics (i.e. complexity of the coronary lesions, diffusely occlusive coronary disease, permanent atrial fibrillation, aspirin allergy). During the first years we usually used a single antiplatelet therapy with $100 \mathrm{mg}$ aspirin daily, while in the last three years (2011-2013) aspirin $100 \mathrm{mg}$ daily plus clopidogrel $75 \mathrm{mg}$ daily was administered for the first 12 months after surgery. Clopidogrel was then discontinued and patients continued life-long aspirin therapy. In the presence of permanent atrial fibrillation anticoagulation therapy was maintained to obtain an international normalized ratio (INR) value $2-2.5$.

\section{Surgical technique}

Access to the heart was obtained through a complete sternotomy in all patients. Myocardial revascularization was performed on-pump or off-pump, according to the surgeon's preference, skill and experience, and in the absence of off-pump contraindications, i.e. left ventricular ejection fraction less than 0.30 , left ventricular end-diastolic diameter greater than $60 \mathrm{~mm}$, diffuse narrowing of coronary arteries, intra-myocardial course of the left descending 
coronary artery (LAD), and emergency or urgent surgery in the presence of perioperative hemodynamic instability [6]. Cardiopulmonary bypass was established by cannulation of the ascending aorta and the right atrium for venous drainage, and cardiac arrest was achieved by the use of antegrade warm blood cardioplegia.

A left internal thoracic artery (LITA) or right internal thoracic artery (RITA) graft was used in all patients for the revascularization of the LAD system. The RITA graft was harvested on patients 60 years old or younger and anastomosed to the LAD, while the LITA was used for the left circumflex artery system. The other bypass grafts were performed by using the saphenous vein harvested under the direct vision technique.

The decision to perform CE and the choice of the technique were mainly based on the preoperative coronary angiographic aspect and/or on the intra-operative findings of the target coronary vessel. In particular, CE was performed when the atheromatous plaques were severe and circumferential and occluded the lumen of the coronary vessel more than half of the diameter, or affected its side branches (i.e. septal perforators or diagonal branches of the LAD, septal perforators of the right posterior descending artery, bifurcations of the obtuse marginal or of the right coronary artery), or the 1.0 or $1.5 \mathrm{~mm}$ probe did not pass the lumen distally, because of severely calcified plaques. After CE, the lumen of the vessel usually reached $1.6-2.2 \mathrm{~mm}$ diameter.

In almost $50 \%$ of cases CE was achieved by the closed technique: the coronary artery was longitudinally incised for a 10-15 mm length and the sclerotic intima was stripped with fine forceps. After the CE procedure, CABG was performed by directly anastomosing the internal thoracic artery or the vein graft on the endarterectomized vessel. In the cases in which CE was performed in open technique, the atheromatous plaques were dissected with a spatula, the arteriotomy was prolonged proximally and distally for several centimeters, and a longer anastomosis was performed using a venous patch for reconstruction of the vessel wall. Intra-operative variables are summarized in Table II.

\section{Definition criteria}

Perioperative myocardial infarction was defined as a postoperative value of troponin I greater than $20 \mathrm{ng} / \mathrm{ml}$ associated with an increase of serum creatine kinase-MB above normal values and more than $10 \%$ of total creatine kinase, and the onset of ECG anomalies.

Major non-cardiac complications were also analyzed: a pulmonary complication was defined as an episode of primary respiratory failure requiring mechanical ventilation for more than $48 \mathrm{~h}$, re-intubation, or intermittent application of non-invasive positive pressure ventilation; permanent neurologic complication owing to focal or general cerebral lesion was defined as a stroke; transient ischemic attack was defined when neurologic symptoms lasted less than $24 \mathrm{~h}$ before disappearing; acute kidney injury was defined as a two-fold increase of preoperative serum creatinine level or oliguria requiring continuous veno-venous
Table II. Intraoperative variables

\begin{tabular}{lc} 
Variable & $\begin{array}{c}\text { Overall } \\
(n=90)\end{array}$ \\
Cardiopulmonary bypass time, mean \pm SD [min] & $101.7 \pm 25.4$ \\
\hline Aortic X-clamp time, mean \pm SD [min] & $62.1 \pm 18.1$ \\
\hline Distal anastomoses, mean \pm SD & $3.1 \pm 0.9$ \\
\hline Left internal thoracic artery on LAD, $n(\%)$ & $79(87.8)$ \\
\hline Bilateral internal thoracic artery, $n(\%)$ & $13(14.4)$ \\
\hline Saphenous vein graft, $n(\%)$ & $84(93.3)$ \\
\hline Off pump surgery, $n(\%)$ & $11(12.2)$ \\
\hline CE on LAD, $n(\%)$ & $65(72.2)$ \\
\hline CE on diagonal branches/Int, $n(\%)$ & $5(5.5)$ \\
\hline CE on RCA/RPD, $n(\%)$ & $18(20.0)$ \\
\hline CE on OM, $n(\%)$ & $7(7.8)$ \\
\hline Multivessel CE, $n(\%)$ & $5(5.5)$
\end{tabular}

CE - coronary endarterectomy, LAD - left anterior descending, RCA - right coronary artery, RPD - right posterior descending, OM - obtuse marginal, SD - standard deviation.

hemodiafiltration. Operative mortality included death in hospital after operation at any time or within 30 days after discharge. Major adverse cardiac and cerebrovascular events (MACCE) was defined as all-cause mortality, non-fatal myocardial infarction, cerebrovascular events, and need of a new coronary revascularization.

\section{Data collection and clinical follow-up}

Data from our institutional database regarding preoperative variables, intraoperative characteristics and postoperative outcomes were retrospectively analyzed. Clinical followup included 6755 patient-months, with a mean duration of $75.1 \pm 36.2$ months, median of 84 months, and was $100 \%$ complete. Clinical follow-up was obtained by personal interview of the patient or of his/her cardiologist, and by recording the results of the non-invasive stress tests and the CCS class for angina. Death was verified on the national registry for deceased people provided by the Italian Ministry of Health. The follow-up was usually performed every 12 months in our outpatient clinic. For patients who could not be included in a regular follow-up in our department, clinical information was obtained by telephone interview. The study followed the principles outlined in the Declaration of Helsinki.

\section{Statistical analysis}

Statistical analysis was performed with Stat View 4.5 (SAS Institute Inc, Abacus Concepts, Berkeley, CA). All continuous values were expressed as mean plus or minus 1 standard deviation of the mean. Student's $t$ test for continuous data and the $\chi^{2}$ or Fisher's exact test for categorical data were used.

The following preoperative and intra-operative variables were analyzed as potential risk factors for death: age, gender, EuroSCORE II Risk Stratification System and STS Adult Cardiac Surgery Risk Score, both expressed as percent risk of death plus or minus 1 standard deviation, presence of 
previous myocardial infarction, smoking habit, co-morbidity (arterial hypertension, diabetes mellitus, chronic renal dysfunction, chronic obstructive pulmonary disease, dyslipidemia, peripheral vascular disease, obesity), Canadian Cardiovascular Society (CCS) grade of angina, the presence of an acute coronary syndrome (i.e. unstable angina), preoperative left ventricular ejection fraction (LVEF), number of diseased coronary artery vessels, need of emergency or urgent $C A B G$, number of grafts per patient, cardiopulmonary bypass and aortic cross-clamp times, the CE technique (closed versus open), the coronary artery target of the CE, including CE performed or not performed on the LAD, perioperative myocardial infarction, the off-pump technique.

Freedom from all-cause death, cardiac death, need of new revascularization, and occurrence of MACCE during the follow-up period was expressed as mean values plus or minus 1 standard deviation, and computed using the KaplanMeier method. Differences between the groups were tested by means of the Mantel-Cox Log-rank test. The Cox proportional hazard method was used to evaluate the influence of variables on time to death in the entire patient population. All $p$-values $<0.05$ were considered statistically significant.

\section{Results}

Left internal thoracic artery was used in $96 \%$ of cases and it was the graft of choice for the LAD in $88 \%$ of patients. In the other cases the graft for the LAD was the RITA (9\%) or the saphenous vein (3\%). Bilateral internal thoracic artery was used in 13 (14.4\%) cases (Table II).

The LAD was treated by CE in $62(68 \%)$ cases, obtuse marginal branches in 7 (8\%) cases, right coronary artery or right descending posterior artery in $14(16 \%)$ cases and diagonal branches in the remaining 2 (2\%) cases. In 5 (5.6\%) patients multivessel CE was performed. Off-pump surgery was performed in 11 (12.2\%) patients (Table II).

In-hospital mortality was $4.4 \%(n=4)$. Postoperative complications were acute kidney injury (5.5\%), re-exploration for bleeding (4.4\%), stroke (1.2\%), and new onset of paroxysmal atrial fibrillation (25\%). The perioperative myocardial infarction rate was $11 \%$ and it represented the main cause of operative mortality ( 2 deaths). The main postop-

Table III. Postoperative outcomes

\begin{tabular}{lc} 
Variables & $\begin{array}{c}\text { Overall } \\
(n=90)\end{array}$ \\
In-hospital mortality, $n(\%)$ & $4(4.4)$ \\
\hline Postoperative LVEF (\%), mean \pm SD & $51.2 \pm 8.4$ \\
\hline Atrial fibrillation, $n(\%)$ & $23(25.5)$ \\
\hline Acute kidney injury, $n(\%)$ & $5(5.5)$ \\
\hline Major bleeding, $n(\%)$ & $4(4.4)$ \\
\hline Neurological injury, $n(\%)$ & $1(1.1)$ \\
\hline Respiratory failure, $n(\%)$ & $7(7.8)$ \\
\hline Myocardial infarction, $n(\%)$ & $10(11.1)$ \\
\hline Postoperative length of stay, mean \pm SD [days] & $8.4 \pm 9.3$ \\
\hline
\end{tabular}

LVEF - left ventricular ejection fraction, SD - standard deviation. erative outcomes are summarized in Table III. A different strategy of antiplatelet therapy proposed did not modify intra-hospital outcomes.

In univariate analysis no factors were detected as a potential predictor of in-hospital myocardial infarction.

\section{Late results}

During follow-up 21 (23.3\%) new deaths occurred: eight for cardiac reasons, three due to malignancy, two due to cerebrovascular events, two due to respiratory failure, two due to renal failure, and four for unknown reasons, which were anyway considered as cardiac for the statistical analysis.

Five- and 10-year survival (not including operative mortality) was $83.3 \pm 4.1 \%$ and $69.6 \pm 6.2 \%$ (Fig. $1 \mathrm{~A}$ ), freedom from cardiac death was $92.7 \pm 2.9 \%$ and $87.3 \pm 4.1 \%$, respectively (Fig. 1 B). When the survival was stratified by age at the time of surgery (older than 70 years versus younger patients), 10-year survival was significantly different (79.0 $\pm 7.7 \%$ vs. $53.3 \pm 8.9 \%$; $p=0.002$ ) (Fig. 1 C). Conversely, when the survival was stratified by the site of CE, 10-year survival was $66.2 \pm 7.5 \%$ (CE performed on the LAD) versus 67.6 $\pm 10.4 \%$ (CE not performed on the LAD) ( $p=0.856)$. Ten-year freedom from cardiac death was better in patients treated by CE on the LAD $(93.2 \pm 3.3 \%)$ in comparison to patients treated by CE not on the LAD $(74.6 \pm 10.2 \%)$, but this difference did not reach statistical significance $(p=0.102)$.

Five- and 10-year freedom from MACCE was $88.9 \pm 3.6 \%$ and $58.2 \pm 10.2 \%$ (Fig. 1 D). At 5 and 10 years, freedom from the need of a new $\mathrm{PCl}$ was $100 \%$ and $77.3 \pm 12.2 \%$, respectively. During the follow-up period 3 patients needed a new PCl: one after 60 months for non-ST elevation myocardial infarction (NSTEMI) due to saphenous vein graft stenosis that was successfully treated by coronary stenting; another one after 90 months for chronic angina related to obtuse marginal branch stenosis, which was treated by medical therapy, and the last one after 95 months due to the progression of an untreated stenosis at the time of surgery. At the coronary angiography in all three patients the vessel treated by CE was still patent. No patients needed redo CABG.

Five- and 10-year freedom from neurological events was $100 \%$ and $97.0 \pm 3.0 \%$. No major bleeding was observed in the whole series.

The use of dual-antiplatelet therapy (DAT) was adopted in 52 patients. We compared them with patients treated with single antiplatelet therapy (SAT, $n=20)$ : At 3, 5 and 7 years freedom from cardiac death was $95 \pm 5 \%, 89 \pm 6 \%$ and $84 \pm 95$ vs. $88 \pm 4 \%, 88 \pm 4 \%$ and $85 \pm 5 \%$ in SAT and DAT groups respectively ( $p=n s$ ), freedom from new $\mathrm{PCI} 100 \%$, $100 \%$ and $93 \pm 6 \%$ vs. 100 in each interval ( $p=n s$ ), freedom from MACCE $95 \pm 5 \%, 79 \pm 9 \%$ and $73 \pm 10 \%$ vs. $88 \pm 4 \%$, $80 \pm 6 \%$ and $75 \pm 6 \%$ ( $p=n s$ ).

\section{Independent predictors of late death and clinical status during follow-up}

In the Cox regression analysis age older than 70 years at the time of surgery $(\mathrm{HR}=2.4 ; 95 \% \mathrm{Cl}: 1.25-12.0 ; p=0.018)$ 

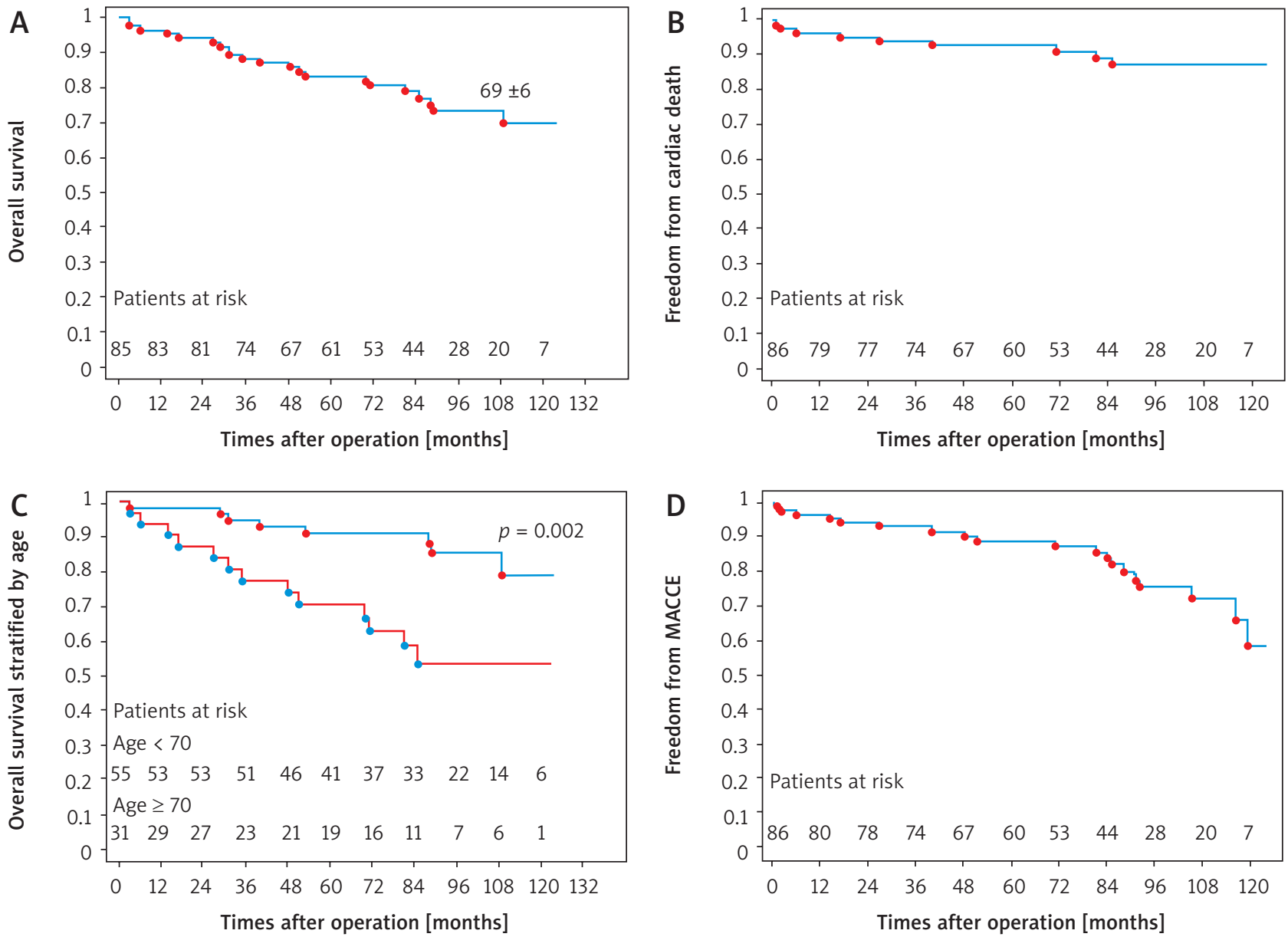

Fig. 1. A - Late survival (not including operative mortality), B - freedom from late cardiac death, C - survival stratified by age, D - freedom from MACCE

and chronic obstructive pulmonary disease $(\mathrm{HR}=2.1$; 95\% Cl: 1.14-44.2; $p=0.036$ ) were identified as independent predictors of death for any cause (Table IV). In particular, preoperative and perioperative myocardial infarction, site and technique of CE were not identified as risk factors of late death ( $p=$ not significant, for all measurements).

Regarding the clinical status of the surviving patients, in only 1 (1.5\%) patient was CCS class 3 recorded; in 5 patients, NYHA class III (7.8\%). No patient had angina or dyspnea at rest. In the entire cohort of patients there was a significant reduction of angina in comparison with the preoperative period ( $p<0.001$ ). Type of antiplatelet therapy used did not significantly influence the long-term results.

\section{Discussion}

Over the last decade there has been a re-emergence of CE, which nowadays might be an important and useful tool in the surgical armamentarium. In our experience the mean incidence of CE during the study period was $5 \%$, with an increase during the last 2 years. In the "current era", patients affected by extensive and diffusive coronary artery disease are the majority. Moreover, after the new recommendations according to the International Guidelines, PCI
Table IV. Predictors of death for any cause during follow-up

\begin{tabular}{lccc} 
Characteristic & $\begin{array}{c}\text { Odds } \\
\text { ratio }\end{array}$ & $95 \% \mathrm{Cl}$ & P-value \\
Age $\geq 70$ & 3.9 & $1.3-12.0$ & 0.02 \\
\hline Postoperative LVEF $\geq 50 \%$ & 0.6 & $0.2-1.9$ & 0.41 \\
\hline $\begin{array}{l}\text { Chronic obstructive pulmonary } \\
\text { disease }\end{array}$ & 7.1 & $1.1-44.2$ & 0.03 \\
\hline Postoperative respiratory failure & 6.0 & $0.8-45.9$ & 0.08 \\
\hline Postoperative AKI & 4.3 & $0.3-53.5$ & 0.26 \\
\hline
\end{tabular}

AKI - acute kidney injury, LVEF - left ventricular ejection fraction.

has become year by year the treatment of choice for coronary patients, including in the presence of left main or multivessel coronary disease [4]. Nevertheless, an untreated residual lesion increases the risk of perioperative myocardial infarction and in-hospital mortality, and it is associated with late recurrence of symptoms and need for new revascularization $[7,8]$. Therefore, in order to achieve complete myocardial revascularization, CE seems to be a mandatory procedure for this complex group of patients undergoing CABG. Its indication and use are destined to increase progressively in the next few years. Since the introduction by Bailey in 1957, many studies have analyzed early and late 
outcomes, tips and tricks, but, nevertheless, its optimal approach is still debated and remains unknown.

The operative mortality in patients undergoing CABG combined with CE ranges from $2.0 \%$ to $6.5 \%$ and appears higher than CABG alone [7-12]. Similarly, in our series, patients undergoing CE presented a preoperative score at lowintermediate risk, i.e. a mean EuroSCORE value of 3.8\% and STS Score value of 1.9\% (Table I), and, as expected, operative mortality was higher than that observed in patients undergoing CABG alone operated on at our institution, i.e. 2-3\%.

A recent meta-analysis of 54,440 patients (7,366 CE patients), enrolled in twenty observational studies by Soylu et al., showed an increased 30-day mortality (OR = 1.69; 95\% Cl: $1.49-1.92 ; p<0.00001)$, perioperative (OR = 2.10; 95\% Cl: $1.82-2.43 ; p<0.00001)$ and post-operative $\mathrm{MI}$ $(\mathrm{OR}=3.34 ; 95 \% \mathrm{Cl}: 1.74-6.41 ; p=0.0003)$ in the $\mathrm{CABG}$ plus CE group in comparison with CABG alone [13]. The incidence of perioperative $\mathrm{MI}$ was $5.9 \%$ (265 events out of 4,518 CE plus CABG patients), and that of postoperative MI, 5.2\% (141 events out of 2,073 CE plus CABG patients), respectively, reporting a $4.3 \%$ operative mortality [13]. Perioperative $\mathrm{MI}$ is an important issue in patients who underwent CABG associated with $\mathrm{CE}$ and it might be one of the main reasons for increased operative mortality. In our experience perioperative $\mathrm{Ml}$ occurred in 10 (11\%) patients and caused the death of $2(16.6 \%)$ patients. Wang et al. in a more recent metaanalysis performed on 63,730 CABG patients found a $10.1 \%$ rate of peri- and postoperative $\mathrm{MI}$; in patients presenting a preoperative high-risk profile and a diffuse disease on the $L A D$, the rate increased to $17.3 \%$ [3]. As expected, the high incidence of myocardial infarction observed in this group of patients can be related not only to the possibility of an acute CE thrombosis due to the loss of endothelial integrity and function, but also to the widespread disease up to the distal portion of the coronary vessels, which does not always allow complete revascularization of myocardium territories. Moreover, also reported by the two above-mentioned metaanalyses [3, 13], the times of cardiopulmonary bypass and cross-clamp during CE plus CABG are usually longer than those observed during CABG alone, consequently increasing the ischemia-reperfusion injury, prolonging renal hypoperfusion with worse outcomes in the early postoperative period. Off-pump CABG may avoid the detrimental effects of the cardiopulmonary bypass and the cardioplegic arrest. However, the complexity of the atherosclerotic lesions and the diffuse disease in the distal portion of the coronary vessels may represent a major limitation to performing this technique. In the meta-analysis published by Wang et al., the rate of off-pump technique in patients undergoing $C E$ plus CABG was $12.7 \%$, similarly to that observed in our experience (11\%). Thirty-day mortality was similar in CE plus off-pump CABG and CE plus on-pump CABG [3]. Similarly, Qiu et al. and Sirivella et al. [14, 15] showed that on-pump versus off-pump CE techniques are associated with similar early and mid-term outcomes.

In order to reduce the incidence of thrombosis, several authors have recommended the use of aggressive post- operative antiplatelet and anticoagulant therapy, varying from dual antiplatelet to lifelong warfarin therapy. Nishigawa et al. in a recently published paper proposed the use of dual antiplatelet therapy in association with warfarin for the first 3 months after CE, following by aspirin only, continued indefinitely. Using this protocol, the patency rate of the internal thoracic artery on the endarterectomized LAD at $13 \pm 12$ months was $96.6 \%$ [16]. In the last 2 years, our policy has consisted in the use of dual anti-platelet aggregation therapy combined with warfarin at least for 12 months after the operation in those patients undergoing CE with the open technique and those presenting a more diffuse multivessel coronary artery disease.

No standard anticoagulation protocol after CE exists [9, 17]. Postoperatively, $100 \mathrm{mg}$ of aspirin and warfarin administration to obtain an INR between 2 and 2.5 are recommended, and then, after 3 months, warfarin is discontinued [17-20]. Postoperative aspirin and clopidogrel administration is another proposed protocol [17].

\section{Late results}

Despite a higher rate of early mortality, several studies have reported that $C E$ in addition to CABG did not affect late survival in comparison with $C A B G$ alone. Since patients requiring $C E$ plus $C A B G$ usually have diffuse coronary artery disease, comparable survival may indicate the beneficial effects of complete revascularization achieved by CE plus CABG $[3,7,12,13]$. In our population of patients the mean number of distal anastomoses per patient was 3.1.

An important investigated aspect that could affect the survival is represented by the site of CE. Some authors have observed a higher late mortality rate when CE was performed on the LAD [21, 22], while other authors [3, 7, 12, 13] did not find the site of CE to be predictor of increased risk. In our cohort, 10-year survival was $66.2 \pm 7.5 \%$ in the CE on LAD group of patients versus $67.6 \pm 10.4 \%$ in the CE not on LAD group. Other potential risk factors that could affect long-term outcome in this patient population have not been clearly investigated. We have observed that patients with a diffusive disease of the coronary artery vessels represent a very complex cohort in which both cardiac and not-cardiac factors can play a crucial role during the follow-up period. Our analysis showed age older than 70 years at the time of the surgery and COPD as independent predictors of late mortality. It is very important to underline how COPD represents a continuing detrimental risk factor for long-term survival, according to other papers already published $[23,24]$. The relationship between COPD and very aggressive atherosclerosis should be clarified in all its aspects. Therefore, the presence of COPD and older age could be considered as potential risk factors to guide the revascularization strategy in a specific direction: avoiding CE in older and COPD patients seems to be a reasonable option, and these subgroups of patients could represent a challenge for cardiac physicians in which an alternative way of revascularization (hybrid, percutaneous if feasible) or just medical therapy should be reconsidered. 
During the follow-up, close monitoring of patients' adherence to antiplatelet aggregation therapy and coronary disease risk factors was conducted. As reported elsewhere, no difference in mid-term outcomes were observed between patients treated with single or dual antiplatelet therapy $[25,26]$. Many authors have emphasized the role of antiplatelet aggregation therapy for the long-term patency rate of the grafts $[27,28]$. This issue is intensively discussed in the international literature, and the patency rate in patients who underwent CE plus CABG is between $40 \%$ and $81.5 \%$. Schwann et al. analyzed the results of 288 patients operated on with CE plus CABG. In this series, the graft failure studied by angiography concerned $33 \%$ of endarterectomized vessels during a mean follow-up of 400 days; therefore, the graft failure following CE was not statistically different from the non-endarterectomized one [29]. In our study we just performed a clinical follow-up so we cannot give any information about this issue.

Only 3 patients (4.6\%, not including in-hospital mortality and all-cause death during follow-up) needed a new $\mathrm{PCl}$ : one after 60 months for NSTEMI due to saphenous vein graft stenosis that was successfully treated by coronary stenting, one after 90 months for chronic angina related to marginal branch stenosis, treated by medical therapy, and the last one after 95 months due to the progression of untreated stenosis at the time of the surgery. In all patients the vessel treated by means of CE was still patent at the coronary angiography. No patient during follow-up needed redo $C A B G$. The observed rate of the need for a new revascularization in our study appears to be comparable to that reported in mid- (5-years) and long-term (10-years) followup, respectively, in the SYNTAX trial and in the CASS Study in patients who underwent CABG [30,31].

Moreover, we have recorded a stable clinical status of patients over time documented by a significant reduction of angina in comparison with the preoperative period.

Finally, an important aspect we observed during followup was the satisfactory freedom from late cardiac death. At 10 years it was $87 \%$ for the entire population of patients, in particular 93\% for those undergoing CE on the LAD. Similarly to that observed in our study, Byrne et al. in 196 patients undergoing CE on the LAD reported $84 \%$ freedom from cardiac events at a follow-up of 5 years.

These data suggest that in terms of long-term results, CE plus CABG is an effective treatment for patients affected by diffusely diseased LAD.

\section{Limitations of the study}

Our study has several limitations: first of all it is retrospective and not randomized. Moreover, we just performed a clinical follow-up and not a graft patency assessment by means of imaging techniques (i.e., CT coronary angiography). We focused our attention on clinical result but further analysis should associate clinical and angiographic results. Therefore, further studies with a larger number of patients, longer follow-up and patency rate evaluation will be necessary to definitely define the real usefulness of CE in ad- dition to CABG. At the same time, a clarification of antiplatelet aggregation-anticoagulation protocols to be used, cardiovascular risk factors and extra-cardiac comorbidity management should be the next mandatory step for these patients.

\section{Conclusions}

Although the operative mortality is higher in comparison with $C A B G$ alone, and the incidence of perioperative myocardial infarction continues to be not negligible, in the presence of diffusely diseased coronary artery vessels CE associated with CABG appears to be an important surgical tool, with acceptable long-term survival and clinical improvement during follow-up. Patients older than 70 years and with COPD represent a new challenge on which to focus attention for the increased risk of late death. Freedom from late cardiac death after CE plus CABG, especially when it is performed on the $L A D$, appears to be very satisfactory.

\section{Disclosure}

The authors report no conflict of interest.

\section{References}

1. Effler DB, Groves LK, Sones FM, Shirey EK. Endarterectomy in the treatment of coronary artery disease. J Thorac Cardiovasc Surg 1964; 47: 98-102.

2. Livesay JJ, Cooley DA, Hallman GL, Reul GJ, Ott DA, Duncan JM, Frazier OH. Early and late results of coronary endarterectomy. Analysis of 3,369 patients. J Thorac Cardiovasc Surg 1986; 92: 649-660.

3. Wang J, Gu C, Yu W, Gao M, Yu U. Short- and long-term patient outcomes from combined coronary endarterectomy and coronary artery bypass grafting: a meta-analysis of 63,730 patients (PRISMA). Medicine (Baltimore) 2015; 94: e1781.

4. Authors/Task Force members, Windecker S, Kolh P, Alfonso F, Collet JP, Cremer J, Falk V, Filippatos G, Hamm C, Head SJ, Jüni P, Kappetein AP, Kastrati A, Knuuti J, Landmesser U, Laufer G, Neumann FJ, Richter DJ, Schauerte P, Sousa Uva M, Stefanini GG, Taggart DP, Torracca L, Valgimigli M Wijns W, Witkowski A. 2014 ESC/EACTS Guidelines on myocardial revascularization: The Task Force on Myocardial Revascularization of the European Society of Cardiology (ESC) and the European Association for Cardio-Thoracic Surgery (EACTS) Developed with the special contribution of the European Association of Percutaneous Cardiovascular Interventions (EAPCI). Eur Heart J 2014; 35: 2541-2619.

5. Rossini R, Musumeci G, Visconti LO, Bramucci E, Castiglioni B, De Servi S, Lettieri C, Lettino M, Piccaluga E, Savonitto S, Trabattoni D, Capodanno D, Buffoli F, Parolari A, Dionigi G, Boni L, Biglioli F, Valdatta L, Droghetti A, Bozzani A, Setacci C, Ravelli P, Crescini C, Staurenghi G, Scarone P, Francetti L, D’Angelo F, Gadda F, Comel A, Salvi L, Lorini L, Antonelli M, Bovenzi F, Cremonesi A, Angiolillo DJ, Guagliumi G; Italian Society of Invasive Cardiology (SICI-GISE); Italian Association of Hospital Cardiologists (ANMCO); Italian Society for Cardiac Surgery (SICCH); Italian Society of Vascular and Endovascular Surgery (SICVE); Italian Association of Hospital Surgeons (ACOI); Italian Society of Surgery (SIC); Italian Society of Anaesthesia and Intensive Care Medicine (SIAARTI); Lombard Society of Surgery (SLC); Italian Society of Maxillofacial Surgery (SICMF); Italian Society of Reconstructive Plastic Surgery and Aesthetics (SICPRE); Italian Society of Thoracic Surgeons (SICT); Italian Society of Urology (SIU); Italian Society of Orthopaedics and Traumatology (SIOT); Italian Society of Periodontology (SIdP); Italian Federation of Scientific Societies of Digestive System Diseases Lombardia (FISMAD); Association of Obstetricians Gynaecologists Italian Hospital Lombardia (AOGOI); Society of Ophthalmology Lombardia (SOL). Perioperative management of antiplatelet therapy in patients with coronary stents undergoing cardiac and noncardiac surgery: a consensus document from Italian cardiological, surgical and anaesthesiological societies. Eurolntervention 2014; 10: 38-46. 
6. Nardi P, Pellegrino A, Bassano C, Mani R, Chiariello GA, Zeitani J, Chiariello L. The fate at mid-term follow-up of the on-pump vs. off-pump coronary artery bypass grafting surgery. J Cardiovasc Med 2015; 16: 125-133.

7. Garcia S, Sandoval Y, Roukoz H, Adabag S, Canoniero M, Yannopoulos D, Brilakis ES. Outcomes after complete versus incomplete revascularization of patients with multivessel coronary artery disease: a meta-analysis of 89,883 patients enrolled in randomized clinical trials and observational studies. J Am Coll Cardiol 2013; 62: 1421-1431.

8. Papakonstantinou NA, Baikoussis NG, Apostolakis E. Coronary endarterectomy: new flavors from old recipes. J Cardiol 2014; 63: 397-401.

9. Tiruvoipati R, Loubani M, Lencioni M, Ghosh S, Jones PW, Patel RL. Coronary endarterectomy: impact on morbidity and mortality when combined with coronary artery bypass surgery. Ann Thorac Surg 2005; 79: 1999-2003.

10. Stavrou A, Gkiousias V, Kyprianou K, Dimitrakaki IA, Challoumas D, Dimitrakakis $\mathrm{G}$. Coronary endarterectomy: the current state of knowledge. Atherosclerosis 2016; 249: 88-98.

11. Byrne JG, Karavas AN, Gudbjartson T, Leacche M, Rawn JD, Couper GS, Rizzo RJ, Cohn LH, Aranki SF. Left anterior descending coronary endarterectomy: early and late results in 196 consecutive patients. Ann Thorac Surg 2004; 78: 867-873.

12. Vohra HA, Kanwar R, Khan T, Dimitri WR. Early and late outcome after offpump coronary artery bypass graft surgery with coronary endarterectomy: a single-center 10-year experience. Ann Thorac Surg 2006; 81: 1691-1696.

13. Soylu E, Harling L, Ashrafian H, Casula R, Kokotsakis J, Athanasiou T. Adjunct coronary endarterectomy increases myocardial infarction and early mortality after coronary artery bypass grafting: a meta-analysis. Interact Cardiovasc Thorac Surg 2014; 19: 462-473.

14. Qiu Z, Chen X, Jiang Y, Wang LM, Xu M, Huang F, Shi H, Zhang C. Comparison of off-pump and on-pump coronary endarterectomy for patients with diffusely diseased coronary arteries: early and midterm outcome. I Cardiothorac Surg 2014; 9: 186

15. Sirivella S, Gielchinsky I, Parsonnet V. Results of coronary artery endarterectomy and coronary artery bypass grafting for diffuse coronary artery disease. Ann Thorac Surg 2005; 80: 1738-1744.

16. Nishigawa K, Fukui T, Yamazaki M, Takanashi S. Ten-year experience of coronary andarterectomy for the diffusely diseased left anterior descending artery. Ann Thorac Surg 2017; 103: 710-716.

17. Takahashi M, Gohil S, Tong B, Lento P, Filsoufi F, Reddy RC. Early and midterm results of off-pump endarterectomy of the left anterior descending artery. Interact Cardiovasc Thorac Surg 2013; 16: 301-305.

18. Takanashi S, Fukui T, Miyamoto Y. Coronary endarterectomy in the left anterior descending artery. J Cardiol 2008; 52: 261-268.

19. Nishi H, Miyamoto S, Takanashi S, Minamimura H, Ishikawa T, Kato Y, Shimizu Y. Optimal method of coronary endarterectomy for diffusely diseased coronary arteries. Ann Thorac Surg 2005; 79: 846-853.
20. Schmitto JD, Kolat P, Ortmann P, Popov AF, Coskun KO, Friedrich M, Sossalla S, Toischer K, Mokashi SA, Tirilomis T, Baryalei MM, Schoendube FA. Early results of coronary artery bypass grafting with coronary endarterectomy for severe coronary artery disease. J Cardiothorac Surg 2009; 4: 52.

21. Brenowitz JB, Kayser KL, Johnson WD. Results of coronary artery endarterectomy and reconstruction. J Thorac Cardiovasc Surg 1988; 95: 1-10.

22. Silberman S, Dzigivker I, Merin O, Shpira N, Deeb M, Britran D. Does coronary endarterectomy increase the risk of coronary bypass? J Card Surg 2002; 17: 267-271.

23. Angouras DC, Anagnostopoulos CE, Chamogeorgakis TP, Rokkas CK, Swistel DG, Connery CP, Toumpoulis IK. Postoperative and long-term outcome of patients with chronic obstructive pulmonary disease undergoing coronary artery bypass grafting. Ann Thorac Surg 2010; 89: 1112-1118.

24. de Miguel-Díez J, Jiménez-García R, Hernández-Barrera V, Carrasco-Garrido P, Bueno H, Puente-Maestu L, Jimenez-Trujillo I, Alvaro-Meca A, Esteban-Hernandez J, de Andrés AL. Time trends in coronary revascularization procedures among people with COPD: analysis of the Spanish national hospital discharge data (2001-2011). Int J Ostruct Pulmon Dis 2015; 10: 2285-2294.

25. Russo M, Nardi, P, Saitto G, Bovio E, Pellegrino A, Scafuri A, Ruvolo G. Single versus double antiplatelet therapy in patients undergoing coronary artery bypass grafting with coronary endarterectomy: mid-term results and clinical implications. Interact Cardiovasc Thorac Surg 2017; 24: 203-208.

26. Bomb R, Oliphant CS, Khouzam RN. Dual antiplatelet therapy after coronary artery bypass grafting in the setting of acute coronary syndrome. Am J Cardiol 2015; 116: 148-154.

27. de Leon N, Jackevicius CA. Use of aspirin and clopidogrel after coronary artery bypass graft surgery. Ann Pharmacother 2012; 46: 678-687.

28. Marinelli G, Chiappini B, Di Eusanio M, Di Bartolomeo R, Caldarera I, Marrozzini $C$, Marzocchi A, Pierangeli A. Bypass grafting with coronary endarterectomy: immediate and long-term results. J Thorac Cardiovasc Surg 2002; 124: 553-560

29. Schwann TA, Zacharias A, Riordan CJ, Durham SJ, Shah AS, Habib RH. Survival and graft patency after coronary artery bypass grafting with coronary endarterectomy: role of arterial versus vein conduits. Ann Thorac Surg 2007; 84: 25-31.

30. Mohr FW, Morice MC, Kappetein AP, Feldman TE, Ståhle E, Colombo A, Mack MJ, Holmes DR Jr, Morel MA, Van Dyck N, Houle VM, Dawkins KD, Serruys PW. Coronary artery bypass surgery versus percutaneous coronary intervention in patients with three-vessel disease and left main coronary artery disease: 5-year follow up of the randomized clinical SYNTAX trial. Lancet 2014; 381: 629-638.

31. CASS Principal Investigators and Their Associates. Myocardial infarction and mortality in the coronary artery surgery study (CASS) randomized trial. N Engl J Med 1984; 310: 750-758. 